\title{
Análisis de casos publicados del indicador ECI del GRI en entes sin fines de lucro. Efectos de la vigencia de la RT36
}

Sergio Miguel Hauque
Prof. titular de Derecho empresario, FCE, UNL
Email: sergiohauque@yahoo.com.ar

María de los Angeles del Barco JTP Contabilidad Básica, FCE, UNL

Email: angelesdelbarco@hotmail.com
Maria Laura Rabasedas

JTP de Introduccción a la Economía, FCE, UNL

Email:mlrabasedas@hotmail.com
Palabras clave

- Balance Social

- Global Reporting Initiative

- Entes sin fines de lucro

- Estado de Valor Agregado

- Valor Económico

\section{Resumen}

El presente trabajo tiene por objeto analizar el contenido en la práctica del indicador EC1 de la Guía de Reportes GRI, en entes sin fines de lucro. Para esto, se realizó un estudio empírico de reportes publicados en los que se observaron las formas de presentación del indicador y sus particularidades. Las conclusiones demuestran que existe una significativa dispersión de formas, contenidos y conceptos que afecta la capacidad de este indicador de generar información verdaderamente útil.

El trabajo se completa con la visión de los autores en relación a los avances y desafíos que presenta el Estado de Valor Económico Generado y Distribuido incorporado por la Resolución Técnica № 36, en reemplazo del EC1.

Keywords

- Social Balance

- Global Reporting Initiative

- Nonprofit Organizations

- Value Added Statement

- Economic Value

\section{Abstract}

This paper aims to analyze the Economic Indicator 1 (EC1) of the GRI Reporting Guidelines, applied on practice to nonprofit organizations. In this regard, an empirical study of published reports was conducted, considering EC1 presentation forms and characteristics. The main findings show that there is a significant dispersion of forms, contents and concepts affecting the ability of this indicator to generate truly useful information.

This work is completed with the author's vision regarding the progress and challenges of the "Generated and Distributed Economic Value Statement" incorporated by the Technical Resolution N036 in replacement of EC1. 